Article

\title{
The Impact of Behavioral Drivers on Adoption of Sustainable Agricultural Practices: The Case of Organic Farming in Turkey
}

\author{
Nuray Cakirli Akyüz * and Ludwig Theuvsen \\ Department of Agricultural Economics and Rural Development, Agribusiness Management, \\ University of Göttingen, 37073 Göttingen, Germany; 1theuvs@gwdg.de \\ * Correspondence: ncakirl@gwdg.de or nuraycakirli@gmail.com
}

Received: 1 July 2020; Accepted: 9 August 2020; Published: 24 August 2020

check for updates

\begin{abstract}
Adoption decisions represent a crucial topic in sustainable agriculture research, particularly in the organic agriculture sector; to understand farmers' decision-making, research has to delve more deeply into the influences of farmers' behavior. The aim of this study, therefore, is to determine the behavioral intentions of Turkish sultana raisin producers toward organic farming practices. The proposed model integrates basic elements of the Theory of Planned Behavior and the technology acceptance model, which is then tested with survey data gathered from conventional and organic farmers by applying structural equation modeling, a powerful multivariate statistical technique. The results reveal that organic agriculture is perceived as a useful low-cost innovation by conventional farmers. Relating the results to group comparisons indicates that members of the conventional group are significantly more likely to have a positive intention towards adopting organic farming practices. Our results suggest possible interventions that policymakers should implement not only to stimulate adoption intentions of conventional farmers, but also to sustain continuance of organic practices by current operators.
\end{abstract}

Keywords: organic farming; adoption; conversion; structural equation modeling; Turkey

\section{Introduction}

Understanding the factors that influence the adoption of agricultural technologies has been a long-standing issue in agricultural economics and agribusiness management research. Among others, an extensive amount of literature on organic agriculture adoption has developed. It addresses the importance of motivational aspects, such as financial, farming-related, and personal motives. Some adoption literature leads to a general outcome that financial drivers, such as price premiums, farm payments, or cost savings, are the main reasons for farmers to convert to organic agriculture [1-4]. However, other authors suggest caution against generalizations for the economic reasons in conversion decisions, since much research has identified non-profit aims and has highlighted the importance of other motivational factors [5-7].

Existing research on farmers' organic agriculture adoption behavior comes mostly from developed countries [8-11]. Consequently, research on the behavioral drivers of organic agriculture adoption in developing and emerging countries has remained scarce so far [12-15]. Additionally, there are not many studies in the organic agriculture adoption literature that focus on the social-psychological factors that influence farmers' decisions about reorienting their agricultural production systems [16-18].

In previous research, individual adoption processes have been examined by applying diverse adoption theories. Whereas Rogers' theory [19] on the adoption and diffusion of innovations applies a technical view, behavioral research highlights various attitude-behavior theories for predicting 
unobservable characteristics of adoption decisions. From the latter perspective, the most popular theoretical approaches are known as Theory of Reasoned Action (TRA) [20,21] and the extended TRA, which refers to the Theory of Planned Behavior (TPB). The TPB, developed by Ajzen [22,23], considers the impact of a subjective norm, attitudes, and perceived behavioral control on the intentional and observable characteristics toward adoption of an innovation. While the vast majority of studies rely on the TPB $[12,14,15,24,25]$, several difficulties in applying the TPB and explaining behavioral drivers [26] led researchers to extend the stated theories, or to apply different models to understand individual perceptions and attitudes toward changes of agricultural and food systems. The Technology Acceptance Model (TAM) [27] is one of the most widely accepted and frequently applied theoretical approaches $[28,29]$ combined with a well-recognized modification of the TPB and the TRA models [30-34].

Regardless of the theory asserted, current research shows increasing evidence on the important role that farmers' perceptions play in the adoption and dissemination of sustainable agricultural technologies, such as organic production, and their satisfaction with system usage [35-37]. However, the wide range of studies on the farmers' attitudes also indicates that it is still challenging to understand the concept of innovation adoption completely. This may be even more complex in developing and emerging countries, since many farmers have been classified as small adopters [15,38,39].

As a consequence of the above-mentioned literature, we conclude that there is still a considerable research gap regarding the role of farmers' attitudes and intentions in the adoption of organic agriculture, particularly in the context of non-developed countries. Therefore, the present study focused on the investigation of the farmers' attitudes and intentions, particularly to understand Turkish farmers' perceptions of organic farming and to determine factors that contribute to the formation of their attitudes and intentions toward adoption and continuance of organic farming. In doing this, the study contributes to the existing literature by extending research on the behavioral drivers for conversion to organic farming in developing and emerging countries. Turkey is one of the leading countries in organic production, with about 524,000 hectares total organic farmland. In 2014, the country ranked as the fifth highest country in growth of organic agricultural land in Europe. This growth rate in organic production is set to increase over the forthcoming years, since large volumes of key crops like cotton, olives, and grapes are currently in conversion to come into regular operation [40]. This rapid growth in organic agriculture has drawn attention and, as a result, the country is referred to as a prime example for an analysis of the impact of behavioral drivers on the adoption of organic farming.

Despite the rapid increase in actual organic farming, as well as those areas of farmland under conversion, the main factors that have had an impact on Turkish farmers' decisions and preferences have remained unclear so far. There are only a few studies on Turkey that explain the factors influencing the choice of agricultural practices that are important in adoption of these practices [41-44]. Moreover, the current work does not address organic farmers' perceptions in the adoption decision. This research gap has been filled by conducting an empirical study based on the TPB and the TAM with survey data gathered from 275 Turkish conventional and organic raisin producers. A comprehensive analysis of the raisin farmers' attitudes and intentions was employed using partial least squares structural equation modeling (PLS-SEM). A comparison of conventional and organic farmers was performed by multi-group analysis [45].

This paper is divided into six sections. The next section explains the theoretical framework and model and formulates the research hypotheses that serve as the basis for the empirical study. The third section describes the sample and the data collection process, then explains the research methodology. The focus of the fourth section is on the results of the causal analysis and the comparison tests of organic and conventional farmers. In the fifth section, the results are discussed. The paper concludes with some policy implications, limitations, and some suggestions for future research in the final section. 


\section{Theoretical Framework and Hypotheses}

For more than two decades, the question of how behavior is determined by values and attitudes has been a center of research interest $[46,47]$. Since the objective of this study is to explore the determinants of behavioral intention toward organic agriculture, we use two approaches to set our theoretical framework: The TPB and the TAM. The TPB, which is rooted in the TRA [20,21] assumes that human behavior is reason-based and guided by three independent constructs: Behavioral beliefs about what will likely occur as a consequence of a behavior, which produce a favorable or unfavorable attitude toward the behavioral intention; normative beliefs about the normative expectations of others and motivations complying with these expectations that lead to perceived social pressure or subjective norm; and control beliefs regarding perceived behavioral controls that facilitate or impede behavior [22].

The TAM, first introduced by Davis [27], is based on the TPB [22,23]. The TAM is specifically tailored for modeling the choice of a user regarding a new information system. Thus, it has been most used to predict user acceptance based on perceived usefulness and perceived ease of use in communication technologies [48,49]. In agricultural and food economics as well as in agricultural extension research, the TAM has emerged as a powerful model for predicting user acceptance and has received considerable empirical support not only with regard to information systems [32,33,50,51], but also with regard to the acceptance of certification systems, precision agriculture, tracking and tracing systems, and renewable energy production, for instance [28,52-58].

In order to predict behavioral intention drivers to adopt or to continue using organic production technologies, the eight constructs mentioned above have been modeled in our framework as the latent variables. The research framework guiding the empirical study is shown in Figure 1.

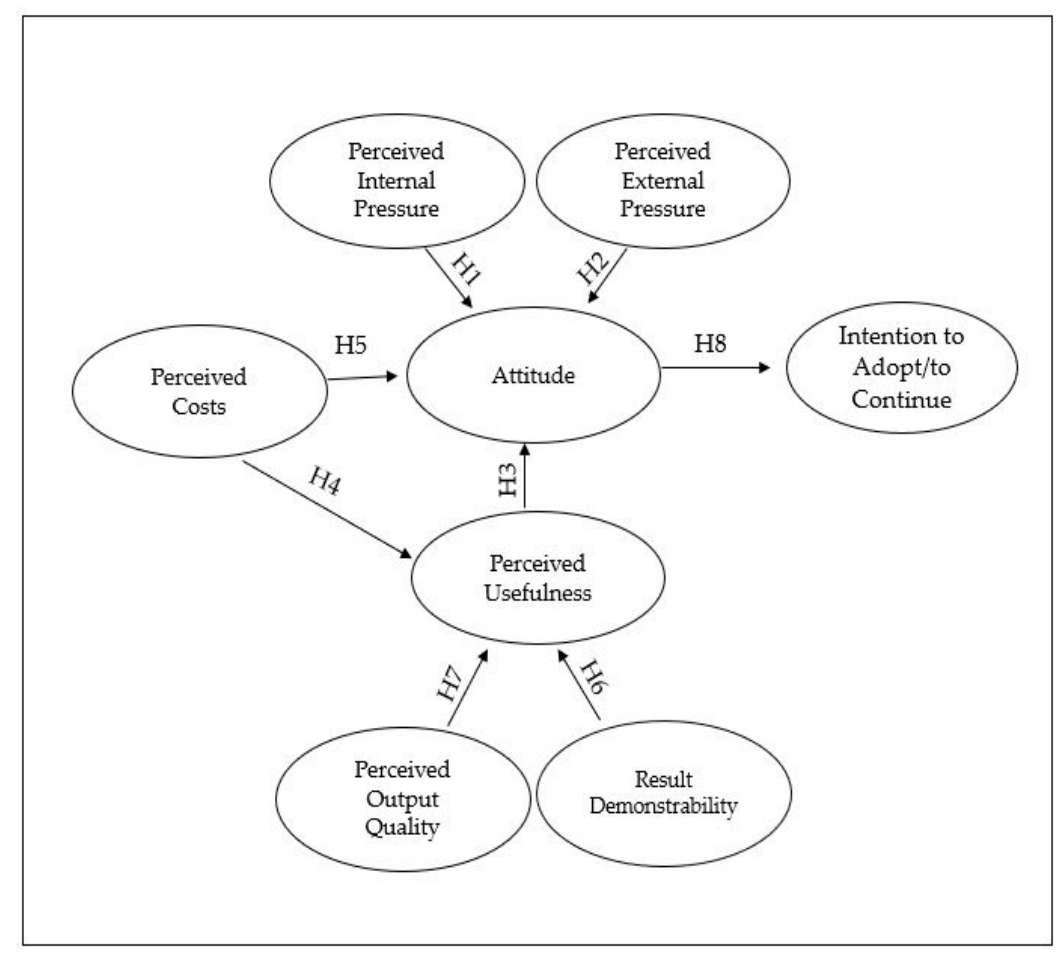

Figure 1. Research model (authors' illustration).

In the following sections, we explain the hypotheses derived from the related literature, which describe the influence perceptions are presumed to have by way of explaining farmers' intentions toward organic production. We also present our research model, the constructs, and the setting of the linkages in our model, which rest on the logic mainly espoused by the basic and suitable aspects of the TPB [22,23] and the TAM [27]. 


\subsection{Subjective Norm}

This construct corresponds to a person's perceived social beliefs and anticipations about being approved or supported by another person or surrounding group of people with respect to a specific attitude [22]. According to Miller [59] (p. 126), the subjective norm describes "the influence of people in one's social environment on behavioral intentions." Consistent with the TRA [20], which is a key theoretical supporting structure to the TAM, the subjective norm defines how the willingness of a person to display a certain behavior is influenced by the expectations of third parties. Both the TPB and the TAM propose that individuals or groups adapt their opinions or change their behaviors as a result of social interactions with other individuals, such as family members, neighbors, and relatives [60].

Since behavior is sometimes only partially controlled by individuals, internal and external factors correspond to subjective normative influences [32]. There is increasing evidence that internal social pressure, particularly from neighborhoods, has a positive effect on the adoption of agricultural technologies [61-64]. In the context of the present literary work, we submit our first hypothesis as follows:

Hypothesis 1 (H1). Perceived internal pressure has a positive influence on attitude.

In line with the TAM [32], it is argued that decision-makers incorporate external beliefs into their own belief structures. Volitional control does not, therefore, fully explain farmers' behavior; it is also affected by the pressure exerted by external stakeholders $[57,58,65,66]$. Given the importance of buyers in indirect marketing channels, farmers deal with a permanent control and feel a pressure from their buyers [67]. Agricultural technology adoption is also strongly associated with cooperative activities; empirical evidence suggests that membership in cooperatives accelerates adoption and production alternative to the industrial models by promoting transformative initiatives and agroecological productive functioning of the lands $[68,69]$. Along with this evidence, it is important to measure potential pressure from external groups when considering the different subjective behaviors of adopters. In this regard, we propose the following hypothesis:

Hypothesis 2 (H2). Perceived external pressure has a positive influence on attitude.

\subsection{Perceived Usefulness}

Perceived usefulness explains the degree to which an individual believes that using the system will help to achieve gains in job performance [32]. According to Davis [51], impacts of social influences and perceptual processes are of importance for the understanding of benefit assessment. It is therefore assumed that organic growers seek benefits from the conversion before the behavioral tendency and the generation of intended use occur.

A transition to organic farming would cause both financial and non-financial benefits [70]. Several studies suggest that farmers perceive organic farming as a profitable alternative to conventional farming, and this could have a positive impact on the tendency toward conversion [1,4,71]. For instance, consumers paying higher prices for organic produce compensate for lower yields in organic farming. This might also lead to farmers having a better income due to price premiums. Farmers who do improve their income perceive the increased usefulness of certified organic farming. Organic production can also bring improved market access and business relationships [72]. In addition to economically visible effects, organic farming eliminates health risks to both farmers and consumers as a result of pesticide use [73]. Alongside the positive health impact, enhanced soil fertility and higher diversity in organic farms create environmentally sustainable production systems and maintain productivity and value for the next generations [74]. In the context of this literature, we evaluate the perceived benefits of organic farming as important drivers of farmers' adoption behavior:

Hypothesis 3 (H3). The greater the perceived usefulness, the more pronounced farmers' attitudes are toward the adoption of organic methods. 


\subsection{Perceived Cost}

The perceived cost is defined as the effort that a farmer perceives in fulfilling the requirements for certified organic production. Cost primarily refers to the costs necessary to formalize the policies and procedures on farms. The certification process in organic production involves several steps, such as documentation, registration, process modification, and organizational adaptation to the procedures. These all might increase the bureaucratic burden $[37,38,52]$. In our framework, perceived ease of use, as a construct from the TAM, is replaced by perceived costs considered relevant for both economic and bureaucratic costs [52,53]. Concerning the TAM and Davis's argument [51], the easier the system is, i.e., cheaper in terms of system preparation, maintenance, and control bureaucracy, the more attractive it is in practice. Against this background, we propose a direct effect on attitude toward converting to organic farming and an indirect effect via perceived usefulness. The negative effects of perceived costs are covered by the following two hypotheses:

Hypothesis 4 (H4). The higher the perceived cost of organic technology transfer, the lower the perceived usefulness of organic production.

Hypothesis 5 (H5). The higher the perceived cost of organic technology transfer, the less positive the attitude toward organic production.

\subsection{Result Demonstrability}

The perception of benefits from technological innovation is positively influenced by having demonstrable results that encompass tangibility from using that technology [75]. Organic farming is classified as a process-oriented type of production, so some relevant attributes might not be detected in the final product. Additionally, although the certification and labeling features of organic production are mandatory, they might not adequately mitigate failures in the markets [36,76]. It is therefore important to obtain visible results both internally and externally, so, in turn, it can be assumed that positive perceptions of organic practices can only arise when the benefits for farmers as well as for external stakeholders can be easily recognized. Following Venkatesh and Davis [32], we assume that it is important for farmers to see visible outcomes of the technologies they adopt, and set the following hypothesis:

Hypothesis 6 (H6). Demonstrable results have a positive influence on perceived usefulness.

\subsection{Perceived Output Quality}

Perceived output quality is defined as how well a system realizes its technical capability, that is, the degree to which a farmer (as a technology user) believes that the system can be operated efficiently [32,77]. It is important to demonstrate the results of whether and to what extent an increase in related work performance and positive outcomes, e.g., improved soil fertility, can be directly attributed to organic farming technology. From a farmer's perspective, several assessments would be paramount in believing that organic products perform better and have more positive effects on the environment compared to conventional production. In addition, training included in national extension programs increases farmers' awareness of alternative farming methods and their performance [78-80]. Specifically, an increased awareness of chemical fertilizer and pesticide use has a positive impact on producers' decisions to adopt organic farming [41]. In the light of this evidence, it is assumed that preconditions for conversion to organic farming and maintenance of organic practices improve farmers' understanding of organic products' quality characteristics, and then attract them to invest into organic practices. This background leads to our seventh hypothesis:

Hypothesis 7 (H7). Output quality of organic agricultural systems has a positive influence on perceived usefulness. 


\subsection{Attitude}

Attitude towards the intent of organic production can be established with the cognitive beliefs and effects individuals perceive with respect to a particular innovation. Beliefs and effects are important instruments with which to explain an individual's acceptance [21]. The TAM [51] also suggests that an individual's attitude towards an innovation can be a key aspect of the actual behavior. The basic assumption in our framework is that farmers' intentions to implement organic production are influenced by their attitudes. Attitudes depend on subjective perceptions and farmers' cost/benefit evaluations concerning the usefulness of organic production. According to the TRA [21], the TAM model [32], and prior studies in this agro-environmental context [81,82], we presume that adoption of or continuity in organic farming is the result of attitudes to do with this particular topic.

Behavioral intention is characterized as the level to which an individual has self-consciously planned an activity to realize or avoid a specific behavior $[28,83]$. Behavioral intention, as an indicator of an individuals' effort in pursuing a behavior, is a strong predictor of actual behavior [84]. We take this information into consideration because we will investigate two different groups of farmers. Our respondents comprise farmers assumed to have some experience of organic production and farmers who have already initiated and endorsed a specific behavior (organic practices). For the latter group, we assume that they show motivated behavior. Therefore, our dependent variable is named "behavioral intention" [85], elaborated as "intention to use'" (a subjective probability that a certain behavior will be performed in the near future) and "intention to continue use", i.e., when an individual intends to continue performing a certain behavior [86,87]. The following hypothesis is formulated for both farmer groups:

Hypothesis 8 (H8). A positive attitude about organic farming has a positive influence on farmers' intention to adopt.

\section{Materials and Methods}

This study is based on data from a structured survey of famers' motivation with respect to organic agricultural production. The data employed in the study were collected during a comprehensive survey of Turkish raisin producers in the province of Manisa. The Aegean region, where the province is located, is known as the first organic production area in Turkey. In the mid-1980s, as a result of export demand, farmers started producing organic sultana raisins and figs in this region. The favorable climatic conditions allow farmers to cultivate a large variety of fruits and vegetables. However, the province is famous as the largest production area for sultana raisins, which represents about $94 \%$ of the country's total production [88].

The data employed for this study were gathered from a comprehensive survey of 275 farmers in seven districts. In total, nineteen villages were visited, and a cross-sectional survey was conducted in those villages from January to April 2015. All the relevant information was collected from organic and conventional farmers in face-to-face interviews. The number and the type of farmers to be surveyed were obtained from village lists and respondents in the villages by using simple random sampling. The questionnaire was designed to capture basic information needed for the context of the study. In order to understand farmers' decision-making process, a number of questions eliciting farmers' perceptions, attitudes, and intentions were included and measured on five-point Likert scales from strongly disagree (1) to strongly agree (5). The items for each construct were adapted from measurements defined and used in previous studies on similar topics $[36,37,55,58]$. The scale items defined to measure latent variables of the research model were presented to respondents as the statements given in Appendix A, Table A1. The full sample after data cleaning consisted of observations from 144 conventional and 131 organic producers. A comparison between conventional and organic samples for all established hypotheses was carried out to test differences between the two farming systems.

For estimating the structural model described in Section 2, data were analyzed by using Smart PLS 3.1 statistical software and applying structural equation modeling (PLS-SEM) methods [89]. 
The SEM-PLS is known as a variance-based approach to structural equation modeling, which is suitable for exploratory studies and where the aim of the study is to identify key driver constructs [90]. Furthermore, the PLS-SEM model, as a variance-based technique, allows small sample sizes, particularly for complex models. In addition, the PLS-SEM does not make assumptions with respect to the distribution of the indicators $[90,91]$.

The analysis and interpretation of PLS models entail a two-stage approach: An assessment of the reliability and validity of the measurement instruments used, and an assessment of the structural model that illustrates relationships between the constructs $[90,91]$. After the research model was built into Smart PLS, the PLS algorithm and bootstrapping procedures were employed in the software. Afterwards, to test group differences, multi-group analysis (MGA) [45] was conducted.

\section{Data Analysis and Results}

\subsection{Sample Statistics}

The farmers in our sample were, on average, 55 years old (Table 1). The average number of years of experience in farming practices was about 34 . The organic farmers were slightly older than conventional farmers and had more farming experience. The two groups had no significant difference in terms of gender, since most of the respondents were male, and most women involved in agricultural activities in the country work in unpaid and unregistered positions [92]. Farmers' education status indicates a higher education level amongst the organic farmers. The number of household members was three on average. Our results related to land and grape area size indicated that organic farms are larger than conventional farms.

Table 1. Sample characteristics.

\begin{tabular}{ccccc}
\hline $\begin{array}{c}\text { Demographic } \\
\text { Characteristics }\end{array}$ & \multicolumn{2}{c}{$\begin{array}{c}\text { Conventional Farmers (C) } \\
N=\mathbf{1 4 4}\end{array}$} & \multicolumn{2}{c}{$\begin{array}{c}\text { Organic Farmers (O) } \\
N=\mathbf{1 3 1}\end{array}$} \\
\hline Variables & Mean & Std.-dev. & Mean & Std.-dev. \\
\hline Farmland (daa) & 72.74 & 79.03 & 166.02 & 187.96 \\
Grapeland (daa) & 41.00 & 33.69 & 57.31 & 44.26 \\
Age (years) & 53.75 & 10.57 & 56.17 & 9.367 \\
Gender (0/1) & 1.00 & 0.08 & 1.00 & 0.07 \\
Farming experience (years) & 32.73 & 12.47 & 35.93 & 10.66 \\
Higher education (0/1) & 0.25 & 0.043 & 0.18 & 0.38 \\
Household size (No.) & 3.05 & 1.26 & 3.41 & 1.69 \\
Off-farm income (0/1) & 0.35 & 0.48 & 0.65 & 0.48 \\
\hline
\end{tabular}

Source: Authors' own calculations. Daa = decares. $\mathrm{N}=$ number of samples.

\subsection{Assessment of the Measurement Model}

The constructs indicated in the model are measured by assigned observable items. Before starting the assessment of the measurement model, we employed confirmatory factor analysis to identify the relevant items for each latent variable. The results of the factor loadings are presented in Appendix A (Table A1) for both conventional and organic farmers. Confirmatory factor analysis items with an outer loading of less than 0.7 [90] were removed (except perceived output quality 3 (POQ3), as it is very close to the criterion) from the latent variables and not included in further analyses in order improve internal consistency and reliability.

Afterwards, we checked the construct reliability and internal consistency with the help of Cronbach's alpha (CRA) and composite reliability (CR) [90]. In order to measure convergent validity between the measures, we assessed the average variance extracted (AVE) using the criterion of Fornell and Larcker [93]. First, each item should significantly load on the respective constructs (CRA > 0.70). Second, the CR of all constructs in the model should be 0.7 or higher [94]. Third, the AVE explains more than half of the indicators' variance on average; therefore, it should be 0.5 or above [93]. The results 
show that all items (except for intention to adopt, which was 0.66 , and, thus, very close to the criterion) have significant loadings of 0.70 or higher CRA values on their respective constructs. The CR values of all constructs are higher than 0.70, and the AVEs of all constructs largely exceed 0.50. To assess discriminant validity, we checked whether the squared correlations between two constructs are lower than the corresponding AVEs [90]. Although the related results were not shown, data analysis also revealed that there was no evidence of any cross-loadings or multicollinearity (collinearity statistics; Variance Inflation Factor VIF $<3.5$, tolerances $<1$ ).

The measurement model was proven by having satisfactory results with respect to all above-mentioned parameters. Table 2 summarizes the construct measurement information for both samples. The discriminant validity results [93], which support that all constructs in the research model truly measure different concepts, are given in Appendix B in Tables A2 and A3 for the conventional sample and organic sample, respectively.

Table 2. Measurement information of the constructs.

\begin{tabular}{|c|c|c|c|c|c|c|c|}
\hline \multirow[b]{3}{*}{ Construct } & \multirow[b]{2}{*}{$\mathbf{N}^{\mathbf{o}}$} & \multicolumn{3}{|c|}{ Conventional Sample } & \multicolumn{3}{|c|}{ Organic sample } \\
\hline & & CRA & CR & AVE & CRA & CR & AVE \\
\hline & Items & $(\geq 0.7)$ & $(\geq 0.7)$ & $(\geq 0.5)$ & $(\geq 0.7)$ & $(\geq 0.7)$ & $(\geq 0.5)$ \\
\hline Perceived internal pressure (PIP) & 4 & 0.81 & 0.939 & 0.794 & 0.835 & 0.954 & 0.838 \\
\hline Perceived external pressure (PEP) & 4 & 0.86 & 0.911 & 0.719 & 0.903 & 0.932 & 0.775 \\
\hline Perceived cost (PC) & 4 & 0.88 & 0.918 & 0.737 & 0.918 & 0.941 & 0.800 \\
\hline Perceived usefulness (PU) & 4 & 0.92 & 0.945 & 0.812 & 0.912 & 0.941 & 0.800 \\
\hline Perceived output quality (POQ) & 3 & 0.89 & 0.934 & 0.826 & 0.782 & 0.857 & 0.670 \\
\hline Result demonstrability (RD) & 3 & 0.89 & 0.933 & 0.823 & 0.823 & 0.891 & 0.731 \\
\hline Attitude (ATT) & 2 & 0.81 & 0.916 & 0.846 & 0.912 & 0.958 & 0.919 \\
\hline Intention to adopt (ItoA) & 2 & 0.66 & 0.847 & 0.736 & & & \\
\hline Intention to continue (ItoC) & 2 & & & & 0.901 & 0.953 & 0.910 \\
\hline
\end{tabular}

\subsection{Assessment of the Structural Model}

The structural model was assessed to evaluate the hypothesized relationships in the proposed research model (cf. Figure 1). A structural model that allows understanding of complex relationships between the dependent and independent variables is represented with its sufficiently high explanatory power $\left(R^{2}\right)$, the effect size of a given predictor construct $\left(f^{2}\right)$, the sign and significance of path coefficients, and statistically significant $t$-values associated with the path coefficient estimates [90,91,95].

For conventional farmers, the variance explained $\left(R^{2}\right)$ for each of the endogenous variables is 0.296 for perceived usefulness, 0.537 for attitude, and 0.749 for intention to adopt. For organic farmers, the $\mathrm{R}^{2}$ values are $0.110,0.529$, and 0.697 respectively. For PLS models, Hair et al. [90] recently considered $R^{2}$ values of $25 \%, 50 \%$, and $75 \%$ as weak, moderate, and substantial, respectively. Taking into consideration the explorative nature of the study and the complexity level of the research model, the corresponding results were found to be quite satisfactory. The predictive relevance, $\mathrm{f}^{2}$, was determined, whereby we found a large effect for attitude for both conventional and organic farmers ( $\geq 0.35$ ) [96], and a medium effect for perceived usefulness for conventional farmers $(\geq 0.15)$. The effect size for perceived internal pressure for organic farmers was found to be close to a medium effect, which is 0.103 . All the other latent variables showed small effects $(\geq 0.02)[96]$.

Both hypothesized effects and group differences were tested by using the Smart PLS bootstrapping method with 5000 samples. The results of the calculations for path coefficients, significance of path estimates, and $t$-values are given and evaluated below (Table 3 ). 
Table 3. Results of the hypothesis testing and group comparison.

\begin{tabular}{|c|c|c|c|c|c|c|c|}
\hline \multicolumn{4}{|c|}{ Conventional Sample } & \multicolumn{3}{|c|}{ Organic Sample } & \multirow{3}{*}{$\begin{array}{c}\text { Group Comparison } \\
\text { IdiffI }\end{array}$} \\
\hline \multirow{2}{*}{ Hypothesis/Paths } & Path & \multirow{2}{*}{$t$-Statistics } & \multirow{2}{*}{ HS } & \multirow{2}{*}{ Path coeff. $(\beta)$} & \multirow{2}{*}{$t$-Statistics } & \multirow{2}{*}{ HS } & \\
\hline & coeff. $(\beta)$ & & & & & & \\
\hline $\mathrm{H} 1 / \mathrm{PIP} \rightarrow \mathrm{ATT}$ & $0.164^{* *}$ & 2.22 & + & $0.382 * * *$ & 3.83 & + & 0.218 \\
\hline $\mathrm{H} 2 / \mathrm{PEP} \rightarrow \mathrm{ATT}$ & $0.367 * * *$ & 4.79 & + & $0.359 * * *$ & 3.75 & + & 0.007 \\
\hline $\mathrm{H} 3 / \mathrm{PU} \rightarrow \mathrm{ATT}$ & $0.313 * * *$ & 5.02 & + & $-0.015^{\mathrm{ns}}$ & 0.17 & - & $0.328^{* * *}$ \\
\hline $\mathrm{H} 4 / \mathrm{PC} \rightarrow \mathrm{PU}$ & $0.130^{\mathrm{ns}}$ & 1.49 & - & $-0.247^{* * *}$ & 3.05 & + & $0.377^{* * *}$ \\
\hline $\mathrm{H} 5 / \mathrm{PC} \rightarrow \mathrm{ATT}$ & $0.187^{* *}$ & 2.66 & - & $-0.118^{*}$ & 1.88 & + & $0.305 * *$ \\
\hline $\mathrm{H} 6 / \mathrm{RD} \rightarrow \mathrm{PU}$ & $0.284^{* * *}$ & 3.49 & + & $0.194^{* *}$ & 2.5 & + & 0.09 \\
\hline $\mathrm{H} 7 / \mathrm{POQ} \rightarrow \mathrm{PU}$ & $0.291^{* * *}$ & 3.64 & + & $0.095^{\mathrm{ns}}$ & 0.91 & - & $0.197 * *$ \\
\hline $\mathrm{H} 8 / \mathrm{ATT} \rightarrow \mathrm{ItoA}$ & $0.866^{* * *}$ & 43.62 & + & $\mathrm{n} / \mathrm{a}^{1}$ & $\mathrm{n} / \mathrm{a}^{1}$ & & $\mathrm{n} / \mathrm{a}^{2}$ \\
\hline $\mathrm{H} 8 / \mathrm{ATT} \rightarrow \mathrm{ItoC}$ & $\mathrm{n} / \mathrm{a}^{1}$ & $\mathrm{n} / \mathrm{a}^{1}$ & & $0.830^{* * *}$ & 26.1 & + & $\mathrm{n} / \mathrm{a}^{2}$ \\
\hline
\end{tabular}

Source: Authors' own calculation. HS = Hypothesis support (hypothesis rejected or accepted). PIP: Perceived internal pressure, PEP: Perceived external pressure, PC: Perceived cost, PU: Perceived usefulness, POQ: Perceived output quality, RD: Result demonstrability, ATT: Attitude, ItoA: Intention to adopt organic farming system. ItoC: Intention to continue organic farming system. $\mathrm{n} / \mathrm{a}^{1}=$ not applicable. The definitions of items of Intention can be divided into two groups-intention to adopt and intention to continue. $t$-value $>2.58$ : Significant difference at 0.01 level; $t$-value $>1.96$ : Significant difference at 0.05 level; $t$-value $>1.64$ : Significant difference at 0.10 level. IdiffI $=$ Difference in path coefficient estimates between groups in absolute value. $\mathrm{n} / \mathrm{a}^{2}=$ not applicable . Related group differences could not be calculated by Smart PLS software. ns $=$ not significant. ${ }^{* * * * * *}$ : Significant, $p<0.1 / 0.5 / 0.001 .+$ sign refers accepted, -sign refers rejected for HS column.

\subsection{Model Estimation and Hypothesis Testing}

In the model, each path is characterized by each hypothesis and path coefficients. The overall model explains $0.87 \%$ (for conventional farmers) and $0.83 \%$ (for organic farmers) of the variance for intention to adopt and intention to continue, respectively.

Table 3 shows the assessment of the hypotheses, the results of the model estimation, and the group comparison results.

The path coefficient values $(\beta)$ can be interpreted as follows: $>0.35$ strong influence, $>0.15$ moderate influence, $>0.02$ weak influence (Cohen, 1988). The results from the hypothesis testing show a positive and significant effect of perceived internal pressure (PIP) on the attitude toward converting to organic production $(\beta=0.16, p<0.05)$, confirming Hypothesis 1 , which is also confirmed for current applicants $(\beta=0.38, p<0.01)$. Similar results with respect to external pressure (PEP) (Hypothesis 2$)$ are found for conventional and organic samples $(\beta=0.37, p<0.01$ and $\beta=0.36, p<0.01$, respectively). The effect of subjective norm on farmers' attitude was found significant for both farmer groups, yet the strength of the effect of perceived internal pressure was higher for organic farmers. To these results, we find support for Hypothesis 1 and Hypothesis 2 in both samples.

Perceived usefulness (PU) has a positive and significant effect on the attitudes (ATT) of conventional farmers $(\beta=0.31, p<0.01)$. This finding is not statistically significantly or positively supported for organic farmers. Here, Hypothesis 3 is supported by the conventional farmer group but rejected by the organic farmer group.

Hypothesis 4 posited that perceived cost (PC) would negatively influence perceived usefulness (PU). While this supposition was not significantly confirmed in the non-adopter (conventional) sample, it did hold true for adopters (organic farmers; $\beta=-0.25, p<0.01$ ). Thus, while we found support for Hypothesis 4 for organic farmers, we must reject Hypothesis 4 in the conventional sample. In Hypothesis 5, we assumed that perceived cost (PC) negatively affects the attitudes of conventional and organic farmers. This assumption was accepted for the organic farmers $(\beta=-0.12, p<0.10)$. Surprisingly, the result for the conventional sample is a significant but positive influence $(\beta=0.19$, $p<0.01)$. Therefore, we accepted our hypothesis for the organic sample, but rejected it for the conventional sample. 
A positive and significant effect of result demonstrability (RD) on the perceived usefulness (PU) of organic production was found for conventional $(\beta=0.28, p<0.01)$ and organic farmer groups $(\beta=0.19$, $p<0.05)$. The results show that the effect of result demonstrability is stronger for non-adopters compared to adopters. The present findings support Hypothesis 6. With respect to the role of perceived output quality (POQ), it positively affects perceived usefulness (PU) of organic agriculture for the conventional group ( $\beta=0.29, p<0.01$ ), whereas the effect of POQ is not significant for the non-adopter group $(\beta=0.09, p>0.10)$. Since we have found support for Hypothesis 7 in the conventional but not in the organic sample, this hypothesis has to be rejected for the organic group (insignificant influence), but can be accepted for the conventional group.

Finally, we found support for Hypothesis 8, that farmers' attitude (ATT) has a positive and significant influence on the intention to adopt organic practices amongst conventional farmers ( $\beta=0.87, p<0.01)$, and has a positive and significant influence on the intention to continue organic farming amongst organic farmers $(\beta=0.83, p<0.01)$.

\subsection{Multi-Group Analysis: Comparison of Adopters and Non-Adopters}

The results of the group comparison tests were calculated by using the bootstrapping method. Table 3 shows results of the group differences with path estimates for individual groups and the $t$-values as the indicator values of a model's explanatory power.

The following major differences are observed from the bootstrapping results for PLS-MGA: In general, the results significantly differ with regard to four out of eight hypothesized relationships. First, the path coefficients for perceived usefulness of the organic production on attitude show significant difference between the groups (IdiffI $=0.328, p<0.01$ ). Second, perceived cost is a construct that depicts significant difference between the two samples. The impact of perceived cost of the organic production system is a stronger determinant of perceived usefulness for adopters than for non-adopters (IdiffI $=0.377, p<0.01$ ). A similar result holds true for the third difference between the groups with regard to the effect of perceived cost on farmers' attitudes toward organic production (IdiffI $=0.305, p<0.05$ ). For this, cost is a very important determinant for organic farmers. Finally, the fourth important finding from the group comparison is reflected by the fact that perceived output quality is a more important driver of perceived usefulness for conventional than for organic farmers (IdiffI $=0.197, p<0.05$ ).

Subjective norm has a significant influence on attitudes of both farmer groups. Although the group difference result is not significant, perceived external pressure is more important for non-adopters than for adopters, whereas perceived internal pressure is more important for organic than conventional producers. Similarly, the impact of the demonstrability of the results on perceived usefulness, although not significant, seems to be more important for conventional than for organic farmers.

All in all, the results related to group comparisons indicate that members of the conventional group are significantly more likely to have a positive intention to adopt organic farming practices. This result is particularly obvious for perceived output quality, perceived cost, and perceived usefulness of the organic agricultural systems. Here, influence of the farmers' perceptions on the usage behavior tends to be greater for conventional farmers.

\section{Discussion of Results}

The goal of the study was to explore the determinants of behavioral intention toward organic agriculture by comparing conventional and organic farmers. Thus, to capture the impressions of intention, we established endogenous variables adapted from the TPB [22,23] and the TAM [27], which are known as key theoretical concepts to address the behavioral drivers of adoption decisions. We conducted our analysis with 275 Turkish organic and conventional sultana raisin producers. In general, the results show that behavioral drivers have substantial direct and indirect effects on farmers' intentions to adopt or maintain organic farming practices. Therefore, we can suggest that our findings support the basic relationships proposed by the TPB and the TAM regarding reorientation of farming practices in Turkish raisin production. 
According to our model estimation results, the path coefficient values of the overall model, which were given $0.87 \%$ for conventional farmers and $0.83 \%$ for organic farmers for intention to adopt and intention to continue, respectively, we find similarities between our results and those of earlier studies. Previous studies that were conducted by using covariance-based methods report coefficient values of $59 \%$ for attitude and $70 \%$ for intention to purchase organic food [97], as well as $48 \%$ for attitude and $82 \%$ for actual behavior to consume organic food [98]. Menozzi et al. [24] give the value of $81 \%$ for intention explanation of the adoption of sustainable agricultural practices, whereas Terano et al. [14] report $77 \%$ for the proportion of total variation in farmers' intention to practice sustainable agriculture. A strong explanatory power ( $80 \%$ ) for behavioral change toward adoption of organic farming is also given in the study by Herath and Wijekoon [15]. For these results, the fit of the structural model and its explanatory power are found quite acceptable.

The results of the hypothesis testing confirm that subjective norm is an important driver for uptake and maintenance of organic agriculture. This finding is consistent with previous findings in related studies $[11,25,36]$. In terms of external pressure, we evaluated the influence of the external factors on farmers' decisions from, for example, buyers, consumers, and the government. We found that government, as a standard-setting institution in organic production and certification, plays a significant role in the adoption decision. The results related to external factors (cf. Table 3, results of the perceived external pressure (PEP) $\rightarrow$ ATT) confirm the results of an earlier study by Getz and Schreck [66], who analyzed the importance of cooperatives on the adoption of organic practices. Similarly, Jahn et al. [67] emphasize the pressure of diverse demands from the organic buyers on farmers. Given an example from the food industry, a study by Heyder et al. [58] investigated the impact of TAM-related variables on food companies' investment decisions in tracking and tracing systems. The study reveals that external pressure for implementation, for instance, by retailers, fosters perceived usefulness of investments into systems for improving traceability and increases the firms' attitudes toward intention to use the systems.

Organic production is known as a labor-intensive farming system [99]. Therefore, in our group comparison results (cf. Table 3 perceived internal pressure (PIP) $\rightarrow$ ATT), internal factors contribute more strongly to the attitudes of organic farmers than to those of conventional producers. Additionally, prior studies revealed a spatial effect in conversion decisions in the sense that a neighboring farm's organic production has a significant and positive influence on farmers' conversion decisions [61,100]. Our finding supports the existing literature.

As expected, the effect of perceived usefulness on the attitude toward organic production was found positive and significant for the conventional farmers. However, the negative (but not significant) effect of the usefulness found for organic producers was surprising (Table 3, perceived usefulness $(\mathrm{PU}) \rightarrow$ ATT). Although conventional farmers expect to obtain useful results in improvement on their business relationships, income, and health-related issues, organic farmers find these issues irrelevant regarding their attitudes toward organic production. The effect of the benefit aspect in decision-making processes of the conventional farmers was studied with the example of Indian farmers. As evidence of our results, Paditar and Paditar [13] found a positive relationship between the perceived usefulness of organic farming and farmers' attitudes toward this farming practice.

In this study, the costs related to compliance with organic production were handled in two ways: Economic costs, which are related to land preparation and certification of production, and bureaucratic costs, which are linked to the control system of certified organic production. According to our results, perceived cost has a significant and negative effect on the perceived usefulness and attitude for the group of organic farmers. This expected result is not supported for the group of conventional farmers; their perception of the cost variable exerts only insignificant influence on the perceived usefulness (cf. Table 3, results of the perceived cost (PC) $\rightarrow$ PU and PC $\rightarrow$ ATT). What is more surprising is that economic and bureaucratic costs have been identified as factors that positively affect the organic production attitude of conventional farmers. This result reveals that financial concerns do not impede 
conventional farmers' positive attitude toward organic production, a result that was also found in earlier studies for certification of food processing companies [100].

Prior work on farmers' motivation and cost factors has shown diverse results. For instance, Schulze et al. [53] indicated the importance of the bureaucratic costs by suggesting the negative effect of such costs on the German farmers' satisfaction with organic production systems. The survey results on Indian farmers' decision-making show that costs have no significant relationship with attitude of conventional respondents [13]. In the study by Bravo et al. [36], while bureaucratic costs have a significant and negative impact on producers, economic costs were not seen as a significant parameter influencing farmers' satisfaction in Chile. In line with this study, Albersmeier et al. [37] found that costs arising from bureaucratic issues, e.g., system documentation, hinder development of organic agriculture in Latin American countries. Contradicting these results, some studies emphasize the insignificant importance of cost factors. Herath and Wijekoon [15] found no difference between adopting and non-adopting coconut growers in terms of the perception of cost and benefit aspects. The study findings presented by Herath and Wijekoon [15] confirm our results by reporting that conventional farmers do not consider costs as a barrier, since they believe that organic products bring higher prices in the marketplace. This is in line with earlier studies on certification systems in agriculture and the food industry, which also revealed that costs are not, per se, inhibiting certification decisions if farms or firms find these costs justified by the system's expected advantages [101,102].

While the results related to perception of the result demonstrability and output quality have positive and significant effects on the perception of the usefulness for both farmer groups, the result related to output quality indicated an insignificant effect on the perceived usefulness for current operators. This finding underscores the notion that perceived output quality does not reveal an important effect on the perceived usefulness of the organic farming system for organic farmers. In a similar context, Schulze et al. [53] explained that the cost-benefit relationship in certified organic production has a negative influence on the effectiveness of perceived system usefulness. Study findings on food producers' investment decisions concerning tracking and traceability systems in Germany are also in line with our insignificant results [58].

All in all, our results show that both conventional and organic respondents show favorable attitudes toward adoption or continuance of organic farming practices. The hypothesis tests confirmed a positive relationship between the attitude and behavioral intention-a strong predictor of actual behavior toward organic production. Behavior is known as an aspect of manifestation of attitude; hence, it explains beliefs or opinions of approval or disapproval toward specific actions that farmers either do or do not carry out [103]. Moreover, the occurrence of attitude, intention, and behavior aspects in social psychology models usually depends on underlying endogenous motivations, whose effects can be considered as causal factors. In consideration of our endogenous constructs, their results address the strong perception toward organic production's positive influence on the realization of actual production behavior.

\section{Conclusions}

Several conclusions can be drawn from our results. Considering their profit expectations, conventional farmers perceive organic agriculture as a useful and affordable innovation. However, the costs of the inspection and certification fees are one of the biggest challenges for small farmers in non-developed countries. In most cases, these farmers are served by internationally accredited bodies and must pay the fees by themselves to use the certificates individually. To deal with this problem, an enabling environment is currently driven by governmental organizations, focusing on cost-cutting efforts. A useful example is registering for a group certificate that enables raisin growers to pay reasonable prices for certification, but still allows them use organic certificates individually. Access to governmental subsidies attracts conventional farmers by enabling them to afford the costs of requirements related to organic production, e.g., leading to compensation for land preparation. Such incentives for farmers during the initial years of conversion should also be available for the 
maintenance of organic agriculture. The adequate maintenance of such incentives will most likely increase the adoption of and continuity in organic agriculture practices.

Consistently with the implications from cost perception, conventional farmers show a higher influence of usefulness in organic systems than organic farmers. In line with growing economic pressure, anticipation of achieving price premiums, and the propagation of organic production [104], these results should be considered further by policymakers and practitioners. Policy implementations aimed at improving farmers' understanding of performance in organic farming, developing a clear understanding of cost-benefit factors, and supporting premium price realization for certified organic products will enhance farmers' intentions to adopt organic practices. In this context, comprehensive and active national policies on organic farming are important tools in attracting farmers' attention to organic production. Farmer education and extension programs in organic production methods and technologies and local advisory services on adoption conditions, including input requirements and costs, development of marketing strategies, and improvement of access to alternative marketing channels, are important elements with which government actions should address the national agenda.

An important implication from the results is that strategies to improve and expand organic agricultural adoption should be addressed and maintained not only to convince farmers to convert their land into organic farming systems, but also to stimulate organic producers to keep organic farming as a continuous production system. To this end, governmental programs and support are necessary to be implemented in a broader sense, not only associated with incentives to encourage organic practices, but also with a focus on issues and challenges related to implementation. The organic sector can derive advantages from long-term policies to improve its efficiency. Dissemination of the core values of organic principles and the development and maintenance of organic practices rely on effective management practices that are more important in organic than conventional agricultural systems. Such practices supported with long-term policies, i.e., subsidies, cost-cutting measures, and group certification incentives, should therefore be extended to improve the spread of organic agriculture and enhance its long-term effectiveness.

Our research provides an overview of farmers' perceptions by comparing conventional and organic producers' behavioral intentions. Within the scope of the study, several important results have been revealed. However, there are constraints on how the results might be generalized and the study's representativeness. The sample reflects the general situation of Turkish sultana raisin producers within the defined region under analysis. Hence, the results do not fully meet criteria for representativeness. Further research in a similar context could address producers of other organic produce, such as hazelnuts, apricots, or dried figs. This might help to obtain more generalizable findings from a wider population of producers. Furthermore, research should also be extended to other developing and emerging economies in order to broaden the regional basis of the research results obtained. In this study, behavioral attitudes toward organic farming were measured by latent variables adapted from the TPB and the TAM. Overall, perception variables strongly predict the intention to implement and maintain organic farming practices. Nevertheless, adopters and potential adopters might perceive the fundamental features of an adoption decision in different ways, and this might ultimately lead to different attitudes and behaviors [105]. With this in mind, when testing similar adoption processes, care should be taken to consider other additional latent variables as well as indicators, which might help develop a deeper understanding of the endogenous constructs of farmers' intentions within a larger and more diverse group of producers.

Whereas a plethora of research concludes that the TPB and the TAM have been proven as useful tools to explain behavioral drivers of individuals taking up technology innovations, there are also critical comments made of these models [26,106]. Thus, researchers are encouraged to review and analyze further developments of these critiques by taking into consideration alternative theoretical explanations of human behavior to validate the models or propose a more comprehensive explanation of the continuance behavior. Current literature reports diverse results with respect to the relationships between behavioral drivers and farm business characteristics, such as farm size, gross farm margin, 
and demographic information [107]. Therefore, these relationships should also be investigated in future studies.

Author Contributions: N.C.A. and L.T. conceived and designed the study together. N.C.A. was responsible for conducting the survey with Turkish farmers. N.C.A. designed and conducted the analysis with the support of L.T., N.C.A. wrote most parts of the paper. L.T. contributed to the Introduction, Data Analysis and Results, and Conclusions sections. All authors have read and agreed to the published version of the manuscript.

Funding: This research was funded by Open Access Publication Funds of the University of Göttingen.

Acknowledgments: We acknowledge support by the Open Access Publication Funds of the University of Göttingen. We also would like to thank Manisa Directorate of Provincial Agriculture and Forestry, The Governor of Manisa province, ETO (Association of Ecological Agriculture), and Ege University, Faculty of Agriculture members, for their support they have given for orientation, sectoral information, farm and farmer access, and information and data collection, and Manisa province raisin producers for their indispensable cooperation to complete the data surveys.

Conflicts of Interest: The authors declare no conflict of interest.

\section{Appendix A}

Table A1. Scale items for construct measures and results of the factor loadings.

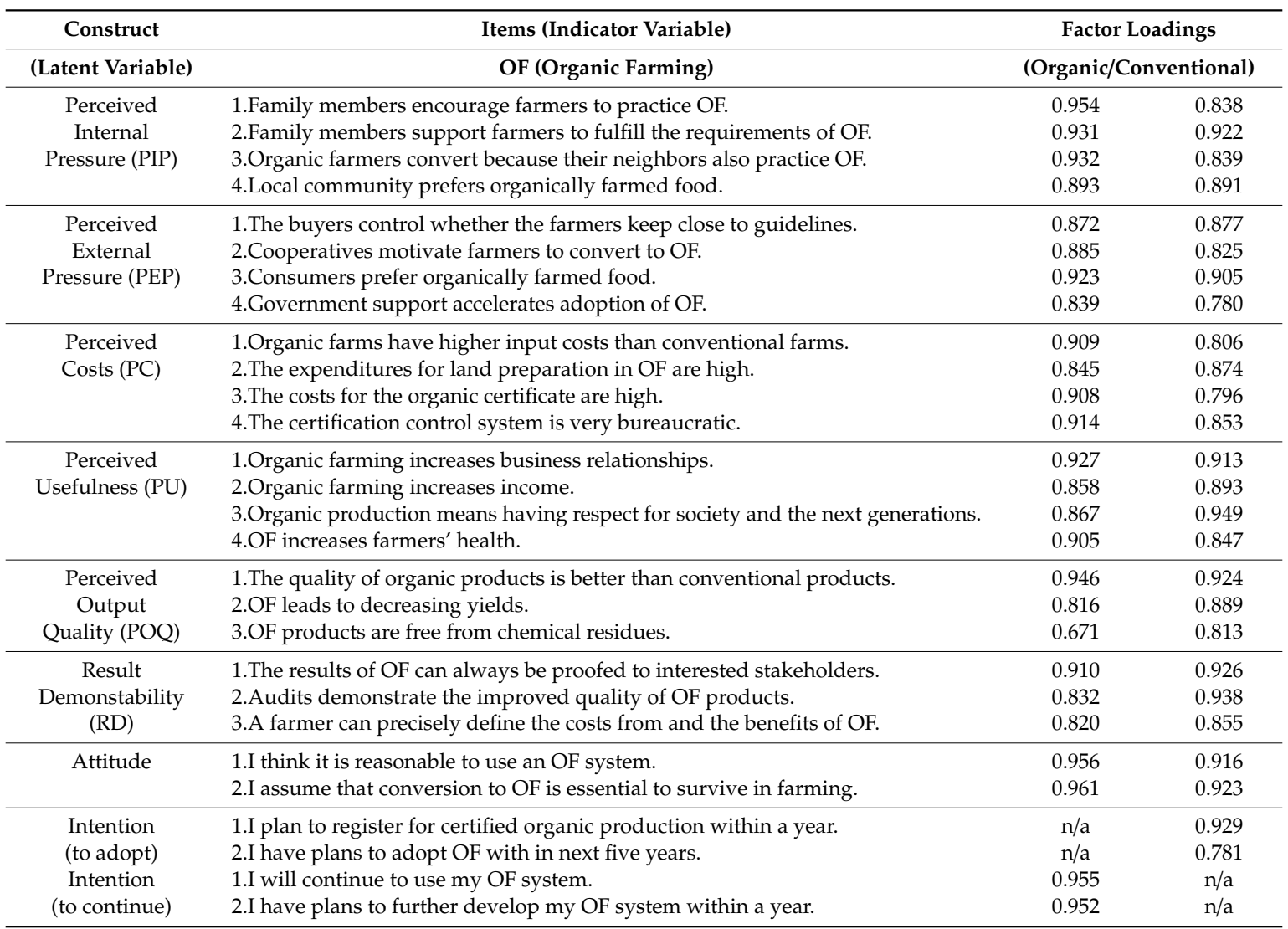

Source: Authors' illustration. Factor loadings: results of the confirmatory factor analysis. n/a = not applicable, as the item measures continuation is related to organic producers, item measures adoption is only linked to conventional producers. 


\section{Appendix B}

Table A2. Discriminant validity of conventional sample.

\begin{tabular}{lcccccccc}
\hline \multicolumn{1}{c}{ Construct } & $\mathbf{1}$ & $\mathbf{2}$ & $\mathbf{3}$ & $\mathbf{4}$ & $\mathbf{5}$ & $\mathbf{6}$ & $\mathbf{7}$ & $\mathbf{8}$ \\
\hline 1 Perceived internal pressure & 0.891 & & & & & & & \\
\hline 2 Perceived external pressure & 0.301 & 0.848 & & & & & & \\
\hline 3 Perceived cost & 0.311 & 0.276 & 0.858 & & & & & \\
\hline 4 Perceived usefulness & 0.260 & 0.398 & 0.264 & 0.901 & & & & \\
\hline 5 Perceived output quality & 0.380 & 0.488 & 0.242 & 0.457 & 0.909 & & & \\
\hline 6 Result demonstrability & 0.426 & 0.460 & 0.222 & 0.451 & 0.473 & 0.907 & & \\
\hline 7 Attitude & 0.415 & 0.593 & 0.422 & 0.551 & 0.553 & 0.478 & 0.920 & \\
\hline 8 Intention to adopt & 0.384 & 0.561 & 0.329 & 0.596 & 0.541 & 0.469 & 0.866 & 0.858 \\
\hline
\end{tabular}

Source: Authors' illustration. Discriminant validity analysis is given based on the Fornell-Larcker [93] criterion. Diagonal elements are square roots of average variance extracted.

Table A3. Discriminant validity of organic sample.

\begin{tabular}{lcccccccc}
\hline \multicolumn{1}{c}{ Construct } & $\mathbf{1}$ & $\mathbf{2}$ & $\mathbf{3}$ & $\mathbf{4}$ & $\mathbf{5}$ & $\mathbf{6}$ & $\mathbf{7}$ & $\mathbf{8}$ \\
\hline 1 Perceived internal pressure & 0.915 & & & & & & & \\
\hline 2 Perceived external pressure & 0.809 & 0.880 & & & & & & \\
\hline 3 Perceived cost & -0.202 & -0.164 & 0.894 & & & & & \\
\hline 4 Perceived usefulness & 0.541 & 0.557 & -0.247 & 0.890 & & & & \\
\hline 5 Perceived output quality & 0.052 & 0.053 & -0.121 & 0.136 & 0.819 & & & \\
\hline 6 Result demonstrability & 0.219 & 0.281 & 0.057 & 0.185 & 0.060 & 0.855 & & \\
\hline 7 Attitude & 0.687 & 0.678 & -0.252 & 0.421 & 0.069 & 0.328 & 0.958 & \\
\hline 8 Intention to adopt & 0.591 & 0.588 & -0.207 & 0.310 & 0.050 & 0.332 & 0.835 & 0.954 \\
\hline
\end{tabular}

Source: Authors' illustration. Discriminant validity analysis is given based on the Fornell Larcker [93] criterion. Diagonal elements are square roots of average variance extracted.

\section{References}

1. Padel, S. Organic grazing livestock production: Possibilities and prospects. In LSIRD Witzenhausen Workshop Proceedings; The James Hutton Institute: Aberdeen, Scotland, UK, 2011. Available online: http://www.macaulay.ac.uk/livestocksystems/witz/padel.htm (accessed on 1 July 2017).

2. Läpple, D.; Rensburg, V. Adoption of organic farming: Are there differences between early and late adoption? Ecol. Econ. 2011, 70, 1406-1414. [CrossRef]

3. Darnhofer, I.; Schneeberger, W.; Freyer, B. Converting or not converting to organic farming in Austria: Farmer types and their rationale. Agric. Hum. Values 2001, 22, 39-52. [CrossRef]

4. Klonsky, K. Forces impacting the production of organic foods. Agric. Hum. Values 2000, 17, $233-243$. [CrossRef]

5. Peterson, H.H.; Barkley, A.; Chacon-Cascante, A.; Kastens, T.L. The motivation for organic grain farmin in the United States; Profits, lifestyle, or the environment? J. Agric. Appl. Econ. 2012, 44, 137-155. [CrossRef]

6. Fowler, S.M.; Lampkin, N.H.; Midmore, P. Organic Farm Incomes in England and Wales 1995/1996; University of Wales, Aberystwyth, Wales, UK. Report for MAFF ref. OF0125. 2000. Available online: http://orgprints.org/8278/1/Organic_Farm_Incomes_03-04.pdf (accessed on 3 May 2018).

7. Offermann, F.; Nieberg, H. Economic performance of organic farms in Europe. In Organic Farming in Europe: Economics and Policy 5; Stolze, M., Haering, A., Eds.; University of Hohenheim: Stuttgart, Germany, 2000.

8. Veldstra, C.; Alexander, E.; Marshall, M.I. To certify or not to certify? Separating the organic production and certification decisions. Food Policy 2014, 49, 429-436. [CrossRef] 
9. Läpple, D.; Kelley, H. Understanding the uptake of organic farming: Accounting for heterogeneities among Irish farmers. Ecol. Econ. 2013, 88, 11-19. [CrossRef]

10. Kallas, Z.; Serra, T.; Gil, J.M. Farmer's objectives as determinant factors of organic farming adoption. In Proceedings of the 113th EAAE Seminar "A Resilient European Food Industry and Food Chain in a Challenging World", Chania, Greece, 3-6 September 2009.

11. Tutkun, A.; Lehmann, B.; Schmidt, P. In Proceedings of the 80th Annual Conference of the Agricultural Economics Society, Paris-Grignon, French, 30-31 March 2006.

12. Issa, I.; Hamm, U. Adoption of Organic Farming as an Opportunity for Syrian Farmers of Fresh Fruit and Vegetables: An Application of the Theory of Planned Behaviour and Structural Equation Modelling. Sustainability 2017, 9, 2024. [CrossRef]

13. Patidar, S.; Patidar, H. A Study of Perception of Farmers towards Organic Farming. Int. J. Appl. Innov. Eng. Manag. 2015, 4, 269-277.

14. Terano, R.; Mohamed, Z.; Shamsudin, M.N.; Latif, İ.A. Factors influencing intention to adopt sustainable agriculture practices among paddy farmers in Kada, Malaysia. Asian J. Agric. Res. 2015, 9, 268-275. [CrossRef]

15. Herath, C.; Wijekoon, R. Study on attitudes and perceptions of organic and non-organic coconut growers towards organic coconut farming. A. Investigaciones. Idesia 2013, 31, 5-14. [CrossRef]

16. Hansson, H.; Ferguson, R.; Olofsson, C. Phychological constructs underlying farmers' decisions to diversify or specialize their business-An application of Theory of Planned Behaviour. J. Agric. Econ. 2012, 63, 465-482. [CrossRef]

17. Barbieri, C.; Mahoney, E. Why is diversification an attractive farm adjustment strategy? Insights from Texas farmers and ranchers. J. Rural Stud. 2009, 25, 58-66. [CrossRef]

18. Beedell, J.D.C.; Rehman, T. Explaining farmers' conservation behavior: Why do farmers behave the way they do? J. Environ. Manag. 1999, 57, 165-176. [CrossRef]

19. Rogers, E.M. Diffusion of Innovations; FP. The Free Press; Macmillan Publishing Co.: New York, NY, USA, 1999; pp. 2-17.

20. Ajzen, I.; Fishbein, M. Understanding Attitudes and Predicting Social Behavior; Prentice-Hall: Englewood-Cliffs, NJ, USA, 1980; pp. 99-106.

21. Fishbein, M.; Ajzen, I. Belief, Attitude, Intention, and Behavior: An Introduction to Theory and Research; Addison-Wesley: Reading, MA, USA, 1975; pp. 298-300.

22. Ajzen, I. The Theory of Planned Behavior. Organ. Behav. Hum. Decis. Process. 1991, 50, 179-211. [CrossRef]

23. Ajzen, I. From intentions to actions: A theory of planned behavior. In Action-Control: From Cognition to Behavior; Springer: Heidelberg, Germany, 1985; Volume 8, pp. 11-39.

24. Menozzi, D.; Firoavanzi, M.; Donati, M. Farmer's motivation to adopt sustainable agricultural practices. Bio-Based Appl. Econ. 2014, 4, 125-147.

25. Hattam, C. Adopting Organic Agriculture: An Investigation Using the Theory of Planned Behavior. 2006. Available online: http://orgprints.org/10182/ (accessed on 4 February 2018).

26. Sniehotta, F.F.; Presseau, J.; Araújo-Soares, V. Time to Retire the Theory of Planned Behavior; Institute of Health and Society, Newcastle University: Newcastle, UK, 2019; Volume 8, pp. 1-7.

27. Davis, F.D. A Technology Acceptance Model for Empirically Testing New End-User Information Systems. Theory and Results. Ph.D. Thesis, Sloan School of Management, Massachusetts Institute of Technology, Cambridge, MA, USA, 1986.

28. Verma, P.; Sinha, N. Integrating perceived economic wellbeing to technology acceptance model: The case of mobile based agricultural extension service. Technol. Forecast. Soc. Chang. 2017, 46, 186-204. [CrossRef]

29. Kargin, B.; Basoglu, N.; Daim, T. Exploring mobile service adoption: Customer preferences. In Proceedings of the 42nd Hawaii International Conference on System Sciences, Big Island, HI, USA, 5-8 January 2009; pp. 1-8.

30. Lai, P.C. The Literature Review of Technology adoption models and theories for the Novelty Technology. J. Inf. Syst. Technol. Manag. 2017, 14, 21-38. [CrossRef]

31. Mathieson, K.; Peacock, E.; Chin, W.W. Extending the Technology Acceptance Model: The Influence of Perceived User Resources. Data Base Adv. Inf. Syst. 2001, 32, 86-112. [CrossRef]

32. Venkatesh, V.; Davis, F.D. A theoretical extension of the technology acceptance model: Four longitudinal field studies. Manag. Sci. 2000, 46, 186-204. [CrossRef] 
33. Szajna, B. Empirical evaluation of the revised technology acceptance model. Manag. Sci. 1996, 42, 85-92. [CrossRef]

34. Chau, P.Y.K. An emprical assessment of a modified technology acceptance model. J. Manag. Inf. Syst. 1996, 13, 185-204. [CrossRef]

35. Adnan, N.; Nordin, S.M.; Rahman, I.; Noor, A. Adoption of green fertilizer technology among paddy farmers: A possible solution for Malaysian food security. Land Use Policy 2017, 63, 38-52. [CrossRef]

36. Bravo, C.P.; Spiller, A.; Villalobos, P. Are organic growers satisfied with the certification system? A causal analysis of farmers' perceptions in Chile. Int. Food Agribus. Manag. Rev. 2012, 15, 115-136.

37. Albersmeier, F.; Schulze, H.; Spiller, A. Evaluation and reliability of the organic certification system: Perceptions by farmers in Latin America. Sustain. Dev. 2009, 17, 311-324. [CrossRef]

38. Dorr, A.C.; Grote, U. The role of certification in the Brazilian fruit sector. Rev. Econ. Conteporanea 2009, 13, 539-571. [CrossRef]

39. Adesina, A.A.; Baidu-Forson, J. Farmers' perceptions and adoption of new agricultural technology: Evidence from analysis in Burkina Faso and Guinea, West Africa. Agric. Econ. 1995, 13, 1-9. [CrossRef]

40. Willer, H.; Lernoud, J. (Eds.) The World of Organic Agriculture. Statistics and Emerging Trends; 2016; Version 1.3; Research Institute of Organic Agriculture, (FiBL): Frick, Switzerland; IFOAM-Organics International: Bonn, Germany, 2016; ISBN FiBL 978-3-03736-307-2, ISBN IFOAM 978-3-944372-15-0.

41. Bektas, Z.K.; Monis, T.; Cikman, A.; İpekcioglu, S.; Cetiner, H.; Nacar, A.S.; Saner, G.; Atis, E. GAP Bölgesinde üreticilerin organic tarıma bakış açıları üzerine bir araştırma (in Turkish). In Research on the Perspectives of Producers on Organic Agriculture in the GAP Region, Proceedings of the GAP VII, Argicultural Congress, Sanliurfa, Turkish; University of Harran: Şanlıurfa, Turkey, 2015.

42. Sezgin, A.; Kaya, T.; Külekçi, M.; Kumbasaroglu, H. Factors affecting the adoption of agricultural innovations in Erzurum province, Turkey. Afr. J. Bus. Manag. 2011, 5, 777-782.

43. Isin, F.; Cukur, T.; Armagan, G. Factors Affecting the Adoption of the Organic Dried Fig Agriculture System in Turkey. J. Appl. Sci. 2007, 7, 748-754.

44. Turkyilmaz, M.K.; Bardakçıoglu, H.E.; Nazligul, A. Socioeconomic factors affecting the adoption of innovations in dairy enterprises in Aydın. Turk. J. Vet. Anim. Sci. 2003, 27, 1269-1275.

45. Sarstedt, M.; Henseler, J.; Ringle, C.M. Multigroup analysis in partial least squares path modeling. In Measurement and Research Methods; Sarsstedt, M., Schwaiger, M., Taylor, C.R., Eds.; Emerald Group Publishing Ltd.: West Yorkshire, UK, 2011; pp. 195-218. [CrossRef]

46. Ajzen, I. The theory of planned behavior: Reactions and reflections. Psychol. Health 2011, 26, $1113-1127$. [CrossRef]

47. Ajzen, I.; Fishbein, M. The Prediction of Behavior from Attitudinal and Normative Variables. J. Exp. Soc. Psychol. 1970, 6, 466-487. [CrossRef]

48. Lee, Y.; Kozar, K.A.; Larsen, K.R.T. The Technology Acceptance Model: Past, Present, and Future. Commun. AIS 2003, 12, 752-780. [CrossRef]

49. Eikebrokk, T.R.; Sørebø, Ø. Technology acceptance in situations with alternative technologies. In NOKOBIT-98, Norsk konferanse for organisasjoners bruk av Informasjons-teknologi, Sesjon; 1998; Volume 2, pp. 89-97. Available online: https://www.nokobit.no/ (accessed on 1 March 2018).

50. Taylor, S.; Todd, P. Assessing IT Usage: The role of prior Experience. MIS Q. 1995, 19, 561-568. [CrossRef]

51. Davis, F.D. Perceived usefulness, perceived ease of use, and user acceptance of information technology. MIS Q. 1989, 13, 319-340. [CrossRef]

52. Jahn, G.; Schramm, M.; Spiller, A. The Reliability of Certification: Quality Labels as a Consumer Policy Tool. J. Consum. Policy 2005, 28, 53-73. [CrossRef]

53. Schulze, H.; Jahn, G.; Spiller, A. Institutional change and acceptance of quality assurance: The case of organic farming in Germany. In Abstract book of EAAE—1st International European Forum on Innovation and System Dynamics in Food Networks; Insbruck-Igls: Tyrol, Austria, 2007.

54. Pierpaolia, E.; Giacomo, C.; Pignattia, E.; Canavaria, M. Drivers of precision agriculture technologies adoption: A literature review. Proced. Technol. 2013, 8, 61-69. [CrossRef]

55. Kröger, R.; Konerding, J.R.; Theuvsen, L. Identification of Factors Influencing the Use of Slurry Solids as Fermentation Substrate in Biogas Plants (in German). Identifikation von Einflussfaktoren auf die Nutzung von Güllefeststoffen als Gärsubstrat in Biogasanlagen. GJAE Ger. J. Agric. Econ. 2016, 65, 112-131. 
56. Mc Donald, R.; Heanue, K.; Pierce, K.; Horan, B. Factors Influencing New Entrant Dairy Farmer's Decision-making Process around Technology Adoption. J. Agric. Educ. Ext. 2015, 22, 163-177. [CrossRef]

57. Emmann, C.H.; Arens, L.; Theuvsen, L. Individual acceptance of the biogas innovation: A structural equation model. Energy Policy 2013, 62, 372-378. [CrossRef]

58. Heyder, M.; Theuvsen, L.; Hollmann-Hespos, T. Investments in tracking and tracing systems in the food industry: A PLS analysis. Food Policy 2012, 37, 102-113. [CrossRef]

59. Miller, K. Communications Theories: Perspectives, Processes, and Context; McGraw-Hill: New York, NY, USA, 2005; pp. 126-128.

60. Park, H.S. Relationships among attitudes and subjective norms: Testing the theory of reasoned action across cultures. Commun. Stud. 2000, 51, 162-175. [CrossRef]

61. Wollni, M.; Andersson, C. Spatial patterns of organic agriculture adoption: Evidence from Honduras. Ecol. Econ. 2014, 97, 120-128. [CrossRef]

62. Bandiera, O.; Rasul, I. Social networks and technology adoption in northern Mozambique. Econ. J. 2006, 116, 869-902. [CrossRef]

63. Staal, S.J.; Baltenweck, I.; Waithaka, M.M.; DeWolff, T.; Njoroge, L. Location and up-take: Integrated household and GIS analysis of technology adoption and land use, with application to smallholder dairy farms in Kenya. Agric. Econ. 2002, 27, 295-315. [CrossRef]

64. Case, A. Neighborhood influence and technological change. Regional Scientific. J. Urban Econ. 1992, 22, 491-508.

65. Sharifzadeh, M.; Zamangi, G.H.; Khalili, D.; Karami, E. Agricultural climate information use: An applicaiton of the planned behaviour theory. J. Agric. Sci. Technol. 2012, 14, 479-492.

66. Getz, C.; Shreck, A. What organic and fair-trade labels do not tell us: Towards a place-based understanding of certification. Int. J. Consum. Stud. 2006, 30, 490-501. [CrossRef]

67. Jahn, G.; Schramm, M.; Spiller, A. The Quality of Audits-A Comparative Study of Auditing and Certification Schemes in the Food Sector. In Proceedings of the 84th EAAE Seminar on 'Food Safety in a Dynamic World', Zeist, The Netherlands, 8-11 February 2004.

68. Abebaw, D.; Haile, M.G. The impact of cooperatives on agricultural technology adoption: Empirical evidence from Ethiopia. Food Policy 2013, 38, 82-91. [CrossRef]

69. Entrena-Duran, F. Deagrarianization, the Growth of the Food Industry and the Construction of New Ruralities. 2018. Available online: https://www.researchgate.net/publication/326106873 (accessed on 3 August 2020).

70. Wynen, E. Conversion from Conventional to Organic Agriculture. In Proceedings of the 36th Annual Conference of the Australian Agricultural Economics Society, Canberra, Australia, 10-13 February 1992.

71. Läpple, D.; Donnelan, T. Farmer attitudes toward converting to organic farming. In Proceedings of the National Organic Conference by the Rural Economy Research Centre (RERC), Teagasc, Athenry, Ireland, 2 December 2008. Available online: http://orgprints.org/18660/1/D.LappleConfpaper08.pdf (accessed on 1 March 2018).

72. Karipidis, P.I.; Athanassiadis, K.; Aggelopoulos, S.; Giompliakis, E. Factors affecting the adoption of quality assurance systems in small food enterprises. Food Control 2009, 20, 93-98. [CrossRef]

73. EP; European Parliament; Human Health Implications of Organic Food and Organic Agriculture. Science and Technology Options Assessment, PE 581922. 2016. Available online: http://www.europarl.europa.eu/ RegData/etudes/STUD/2016/581922/EPRS_STU(2016)581922_EN.pdf (accessed on 3 January 2017).

74. Mader, P.; Maeder, P.; Fliessbach, A.; Dubois, D.; Gunst, L.; Fried, P.; Niggli, U. Soil Fertility and Biodiversity in Organic Farming. Science 2002, 296, 1694-1697. [CrossRef]

75. Moore, G.C.; Benbasat, I. Development of an instrument to measure the perceptions of adopting an information technology innovation. Inf. Syst. Res. 1991, 2, 192-222. [CrossRef]

76. Giannakas, K. Information asymmetry and consumption decisions in organic food product markets. Can. J. Agric. Econ. 2002, 50, 35-50. [CrossRef]

77. Agarwal, R.; Prasad, J. The role of innovation characteristics and perceived voluntariness in the acceptance of information technologies. Decis. Sci. 1997, 28, 557-582. [CrossRef]

78. MoFAL; The Ministry of Turkish Food; Agriculture and Livestock; Organik Tarım Stratejik Planı. Organic Agriculture Strategic Plan 2012-2016. 2012. Available online: http://www.trakya2023.com/uploads/docs/ 2806201331nTii.pdf (accessed on 3 April 2018). 
79. Demiryürek, K.; Stopes, C.; Guzel, A. Organic agriculture: The case of Turkey. Outlook Agric. 2008, 37, 261-267. [CrossRef]

80. Ozbilge, Z. An Analysis of Organic Agriculture in Turkey: The Current Situation and Basic Constraints. J. Cent. Eur. Agric. 2007, 8, 213-222.

81. Wauters, E.; Bielders, C.; Poesen, J.; Govers, G.; Mathijs, E. Adoption of soil conservation practices in Belgium: An examination of the Theory of Planned Behavior in the agri-environmental domain. Land Use Policy 2010, 27, 86-94. [CrossRef]

82. Fielding, K.S.; Terry, D.J.; Masser, B.M.; Hogg, M.A. Integration social identity theory and the theory of planned behavior to explain decisions to engage in sustainable agricultural practices. Br. J. Soc. Psychol. 2008, 47, 23-48. [CrossRef]

83. Warshaw, P.; Davis, F. The accuracy of behavioral intention versus behavioral expectation for predicting behavioral goals. J. Psychol. 1995, 119, 599-602. [CrossRef]

84. Venkatesh, V.; Morris, M.G.; Davis, G.B.; Davis, F.D. User acceptance of information technology: Toward a Unified View. MIS Q. 2003, 27, 425-478. [CrossRef]

85. Kantola, S.J.; Syme, G.J.; Campbell, N.A. The role of individual differences and external variables in a test of the sufficiency of Fishbein's model to explain intentions to conserve water. J. Appl. Soc. Psychol. 1982, 12, 70-83. [CrossRef]

86. Kelly, E.; Heanue, K.; Buckley, C.; O'Gorman, C. Proven Science versus Farmer Perception. In Proceedings of the Agriculture in an Interconnected World, Proceedings of the 29th ICAE International Conference for Agricultural Economists, Milan, Italy, 9-14 August 2015; pp. 1-34.

87. Wunderlich, P.; Kranz, J.; Totzek, D.; Veit, D.; Picot, A. The Impact of endogenous Motivations on Adoption of IT-Enabled Services: The Case of Transformative Services in the Energy Sector. J. Serv. Res. 2012, 16, 356-371. [CrossRef]

88. MoFAL; Ministry of Food, Agriculture and Livestock. Manisa Directorate of Provincial Food Agriculture and Livestock; Statistics: Manisa, Turkey, 2014. Available online: http://manisa.tarim.gov.tr/Menu/11/TarimsalVeriler-) (accessed on 2 March 2018).

89. Ringle, C.M.; Wende, S.; Becker, J. SmartPLS 3. Boenningstedt: SmartPLS GmbH. Available online: www.smartpls.com (accessed on 4 February 2018).

90. Hair, J.; Hult, G.T.; Ringle, C.M.; Sarstedt, M. A Primer on Partial Least Squares Structural Equation Modeling, 2nd ed.; Sage: Thousand Oaks, CA, USA, 2013.

91. Henseler, J.; Ringle, C.M.; Sinkovics, R.R. The use of partial least squares path modeling in international marketing. Adv. Int. Mark. 2009, 20, 277-319.

92. TUIK. Türkiye Istatistik Kurumu. In The Summary of Agricultural Statistics, 16056; Turkish Statistical Office: Ankara, Turkey, 2014. Available online: http://www.tuik.gov.tr/PreHaberBultenleri.do?id=1605632 (accessed on 3 January 2018).

93. Fornell, C.; Larcker, D.F. Evaluation structural equation models with unobservable variables and measurement error. J. Mark. Res. 1981, 18, 39-50. [CrossRef]

94. Nunnally, J.C.; Bernstein, I.H. Psychometric Theory, 3rd ed.; MacGraw Hill: New York, NY, USA, 1994; pp. 303-315.

95. Baumgartner, H.; Homburg, C. Applications of structural equation modeling in market-ing and consumer research: A review. Int. J. Res. Mark. 1996, 13, 139-161. [CrossRef]

96. Cohen, J. Statistical Power Analysis for the Behavioral Sciences; Lawrence Erlbaum: Hillsdale, MI, USA, 1988; pp. 407-416.

97. Saba, A.; Messina, F. Attitudes towards organic foods and risk/benefit perception associated with pesticides. Food Qual. Prefer. 2003, 14, 637-645. [CrossRef]

98. Tarkiainen, A.; Sundqvist, S. Subjective norms, attitudes and intentions of Finnish consumers in buying organic food. Br. Food J. 2005, 107, 808-822. [CrossRef]

99. Morison, J.; Hine, R.; Pretty, J. Survey and analysis of labour in organic farms in the UK and Rebuplic of Ireland. Int. J. Agric. Sustain. 2005, 3, 24-43. [CrossRef]

100. Bjørkhaug, H.; Blekesaune, A. Development of organic farming in Norway: A statistical analysis of neighbourhood effects. Geoforum 2013, 45, 201-210. [CrossRef] 
101. Schulze, H.; Albersmeier, F.; Gawron, J.C.; Spiller, A.; Theuvsen, L. Heterogeneity in the evaluation of quality assurance systems: The international food standard (IFS) in European agribusiness. Int. Food Agribus. Manag. Rev. 2008, 11, 99-139.

102. Gawron, J.-C.; Theuvsen, L. The international food standard: Bureaucratic burden or helpful management instrument in global markets? Empirical results from the German food industry. J. Int. Food Agribus. Mark. 2009, 21, 239-252. [CrossRef]

103. Willock, J.; Deary, I.J.; Edwards-Jones, G.; Gibson, G.J.; McGregor, M.J.; Sutherland, A.; Dent, J.B.; Morgan, O.; Grieve, R. The Role of Attitudes and Objectives in Farmer Decision-Making: Business and Environmentally Oriented Behaviour in Scotland. J. Agric. Econ. 2008, 50, 286-303. [CrossRef]

104. Aksakal, V.; Haşimoğlu, S.; Bayram, B.; Erdoğan, Y.; Altun, H.; Ürüşan; Cengiz, M.M. Sustainability organic agriculture and Livestock production with respect to EU in Eastern Anatolia and East Black Sea regions. Turk. J. Agric. Food Sci. Technol. 2014, 4, 1024-1030.

105. Kossahl, J.; Kranz, J.; Kolbe, L. A perception-based model for smart grid adoption of distribution system operators. In Proceedings of the Eighteenth Americas Conference on Information Systems, Seattle, WA, USA, 9-11 August 2012.

106. Röcker, C. Why Traditional Technology Acceptance Models Won't Work for Future Information Technologies. Int. J. Inf. Commun. Eng. 2010, 65, 237-243.

107. Martínez-García, C.G.; Dorward, P.T.; Rehman, T. Factors influencing adoption of improved grassland management by small-scale dairy farmers in central Mexico and the implications for future research on smallholder adoption in developing countries. Livest. Sci. 2013, 152, 228-238. [CrossRef]

(C) 2020 by the authors. Licensee MDPI, Basel, Switzerland. This article is an open access article distributed under the terms and conditions of the Creative Commons Attribution (CC BY) license (http://creativecommons.org/licenses/by/4.0/). 